This document was prepared in conjunction with work accomplished under Contract No. DE-AC09-96SR18500 with the U. S. Department of Energy.

\title{
DISCLAIMER
}

This report was prepared as an account of work sponsored by an agency of the United States Government. Neither the United States Government nor any agency thereof, nor any of their employees, nor any of their contractors, subcontractors or their employees, makes any warranty, express or implied, or assumes any legal liability or responsibility for the accuracy, completeness, or any third party's use or the results of such use of any information, apparatus, product, or process disclosed, or represents that its use would not infringe privately owned rights. Reference herein to any specific commercial product, process, or service by trade name, trademark, manufacturer, or otherwise, does not necessarily constitute or imply its endorsement, recommendation, or favoring by the United States Government or any agency thereof or its contractors or subcontractors. The views and opinions of authors expressed herein do not necessarily state or reflect those of the United States Government or any agency thereof. 


\section{TECHNICAL REVIEW OF SRS DOSE RECONSTRUCTION METHODS USED BY CDC}

Ali A. Simpkins

Technical Reviewer

July 2005

Westinghouse Savannah River Company Savannah River Site

Aiken, SC 29808

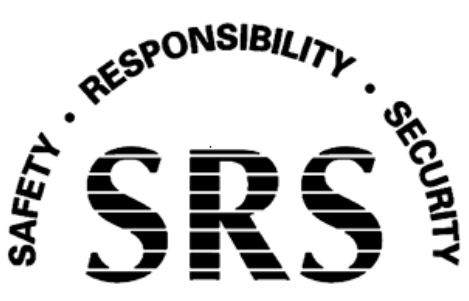




\section{DISCLAIMER}

This report was prepared as an account of work sponsored by an agency of the United States Government. Neither the United States Government nor any agency thereof, nor any of their employees, makes any warranty, express or implied, or assumes any legal liability or responsibility for the accuracy, completeness, or usefulness of any information, apparatus, product, or process disclosed, or represents that its use would not infringe privately owned rights. Reference herein to any specific commercial product, process, or service by trade name, trademark, manufacturer, or otherwise does not necessarily constitute or imply endorsement, recommendation, or favoring by the United States Government or any agency thereof. The views and opinions of authors expressed herein do not necessarily state or reflect those of the United States Government or any agency thereof. 
$\begin{array}{ll}\text { Key Words } & \text { Dose Determination } \\ \text { Tritium } \\ \text { Iodine }\end{array}$

Retention: Lifetime

\title{
TECHNICAL REVIEW OF SRS DOSE RECONSTRUCTION METHODS USED BY CDC
}

\author{
A. A. Simpkins
}

Issued: July 2005

SRNL

SAVANNAH RIVER NATIONAL LABORATORY

AIKEN, SC 29808

Westinghouse Savannah River Company Savannah River Site Aiken, SC 29808

PREPARED FOR THE U.S. DEPARTMENT OF ENERGY UNDER CONTRACT NO. DE-AC09-96SR18500 


\section{ABSTRACT}

At the request of the Centers for Disease Control and Prevention (CDC), a subcontractor Advanced Technologies and Laboratories International, Inc.(ATL) issued a draft report estimating offsite dose as a result of Savannah River Site operations for the period 19541992 in support of Phase III of the SRS Dose Reconstruction Project. The doses reported by ATL differed than those previously estimated by Savannah River Site SRS dose modelers for a variety of reasons, but primarily because 1) ATL used different source terms, 2) ATL considered trespasser/poacher scenarios and 3) ATL did not consistently use site-specific parameters or correct usage parameters. The receptors with the highest dose from atmospheric and liquid pathways were within about a factor of four greater than dose values previously reported by SRS. A complete set of technical comments have also been included. 
TABLE OF CONTENTS

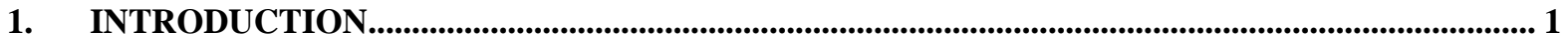

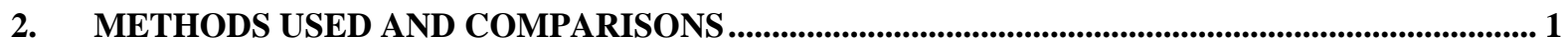

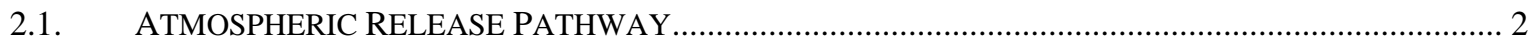

2.1.1. Source Terms .............................................................................................

2.1.2. Scenario Selection ......................................................................................... 3

2.1.3. Dose Comparison for 'Child born in 1955 Outdoors Person' Scenario ......................................... 7

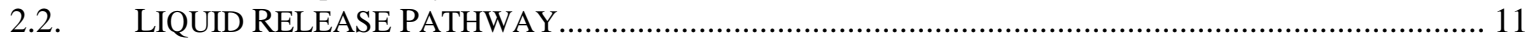

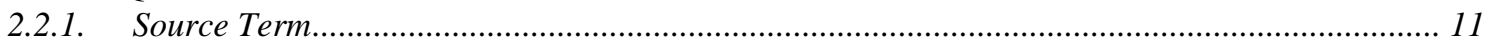

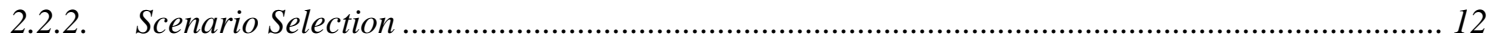

2.2.3. Dose Comparison with 'Delivery Person Adult' ........................................................................... 13

2.2.4. Dose Comparison with 'Near River Adult' .................................................................................. 13

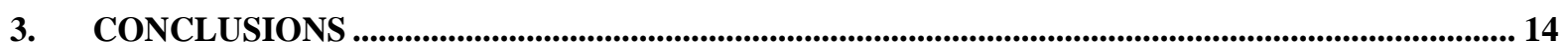

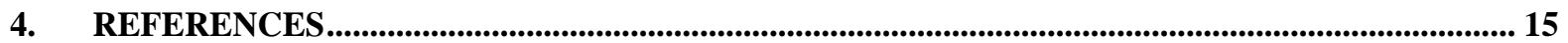




\section{LIST OF TABLES}

TABLE 1. SOURCE TERM COMPARISON 2

TABLE 2 ATMOSPHERIC EXPOSURE PATHWAYS INCLUDED IN DOSE RECONSTRUCTION .. 6 TABLE 3 COMPARISON OF RAP REPORT DOSE VERSUS PHASE III DOSE .................................. 7

TABLE 4 PATHWAY-SPECIFIC DOSE COMPARISON FOR I-131 ............................................... 8

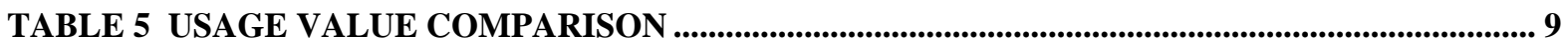

TABLE 6 MAXIMUM EDIBLE WEIGHT FROM ONSITE DEER HUNTS .......................................... 10

TABLE 7 I-131 TRANSFER FACTORS USED BY ATL AND SRS .................................................... 10

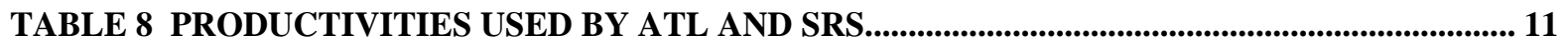

TABLE 9 LIQUID RELEASE SOURCE TERMS....................................................................................... 11

TABLE 10. EXPOSURE LOCATIONS FOR SURFACE WATER RELEASES BY SCENARIO ......... 12

TABLE 11. LIQUID DOSE COMPARISON BY RADIONUCLIDE FOR DELIVERY PERSON

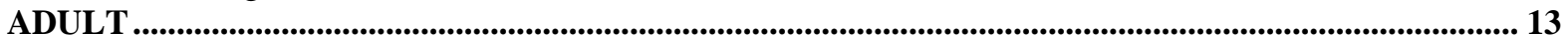

TABLE 12 LIQUID DOSE COMPARISON BY RADIONUCLIDE FOR NEAR RIVER ADULT........ 14

\section{LIST OF FIGURES}

Figure 1 Virtual Source Locations used by ATL ............................................................................................. 3

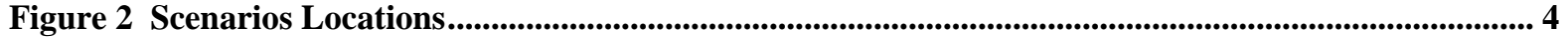

Figure 3 Wind rose for $\mathbf{H}$ Area 1997-2001 (Weber 2002) ............................................................................. 5 


\title{
TECHNICAL REVIEW OF SRS DOSE RECONSTRUCTION METHODS USED BY CDC
}

\author{
By A. A. Simpkins \\ Savannah River National Laboratory \\ Westinghouse Savannah River Company \\ Savannah River Site \\ Aiken, SC 29808
}

\section{INTRODUCTION}

The Savannah River Site (SRS) Dose Reconstruction Project examines releases from the SRS and their associated doses and risks. Phase I of the project involved a review of available documents at SRS and the development of a document database. Phase II involved the initial source term development and pathway analysis which included estimating the amount of radioactive materials and toxic chemicals released to the environment from SRS for the period from 1954 to 1992. Phase III involves estimating a screening dose for this same time period.

The Dose Reconstruction Project is sponsored by the Centers for Disease Control and Prevention (CDC). Phases I and II are complete and Phase III results have been issued in draft. The contractor performing the work for CDC was Advanced Technologies and Laboratories International, Inc.(ATL).

SRS has an extensive Radiological Assessment Program (RAP) which has estimated dose for a variety of radionuclides for the entire period of operation for SRS. These results have also been summarized in one document by Carlton (1998). Doses are also reported yearly in the annual environmental reports. Phase III results differ from previously published SRS results (Carlton 1998) and these differences are discussed here. Throughout this report, the term 'SRS dose' refers to doses estimated by SRS personnel contained within the Environmental Dosimetry Group. A complete list of technical comments is included in their entirety in Appendix A.

\section{METHODS USED AND COMPARISONS}

Dose reconstruction efforts utilize the source terms previously developed during Phase II of the dose reconstruction (Till 2001) as a basis to predict dose to offsite receptors for aqueous and atmospheric releases to the environment and their associated risks. ATL used the transport and dosimetry code GENII (Napier 1988) for these estimates and applied sitespecific parameters in some instances. Since atmospheric and aqueous release dose methods differ, they will be discussed separately below. 


\subsection{Atmospheric Release Pathway}

ATL estimated doses from atmospheric releases for 16 radionuclides and four release locations. The primary contributors to dose were H-3, I-131 and Ar-41 so these radionuclides will be discussed in detail.

\subsubsection{Source Terms}

Table 1 shows the source term reported by various entities. The first column of values contains the source terms as reported in the Annual Environmental Reports (AER) for the years 1954-1992 as taken from Carlton (1998). The second and third numerical columns show the source terms developed by the Radiological Assessment Corporation (Phase II) and ATL (Phase III). Using Phase III as the constant, the following columns show the percent difference with previously reported values.

Table 1 Source Term Comparison

\begin{tabular}{|l|c|c|c|r|r|}
\hline Rad & $\begin{array}{c}\text { SRS AER } \\
(\mathrm{Ci})\end{array}$ & $\begin{array}{c}\text { Phase II Total } \\
(\mathrm{Ci})\end{array}$ & $\begin{array}{c}\text { Phase III } \\
\text { Total } \\
(\mathrm{Ci})\end{array}$ & $\begin{array}{l}\text { \% diff } \\
(\mathrm{P} 3-\mathrm{SRS}) / \mathrm{P} 3\end{array}$ & $\begin{array}{l}\text { \% diff } \\
\text { (P3- } \\
\text { P2)/P3 }\end{array}$ \\
\hline $\mathrm{H}-3$ & $2.55 \mathrm{E}+07$ & $2.60 \mathrm{E}+07$ & $2.51 \mathrm{E}+07$ & $-2 \%$ & $-4 \%$ \\
\hline Ar-41 & $6.40 \mathrm{E}+06$ & $6.40 \mathrm{E}+06$ & $6.36 \mathrm{E}+06$ & $-1 \%$ & $-1 \%$ \\
\hline $\mathrm{I}-131$ & $2.52 \mathrm{E}+03$ & $5.70 \mathrm{E}+04$ & $4.91 \mathrm{E}+04$ & $95 \%$ & $-16 \%$ \\
\hline
\end{tabular}

The tritium source term includes both elemental and oxide releases. For the difference in tritium source term, ATL explains that data from the environmental reports for 1990-1992 was used rather than the reactor estimates for these years as was done in Phase II and they claim the totals from the environmental reports resulted in a somewhat larger source term. However this statement does not agree with the data since their reported source term is actually smaller than those reported both by SRS and during Phase II.

For the argon, the agreement is excellent for all sources of data. For the iodine-131, Phase II source term estimates resulted in a much larger source term than previously predicted by SRS. Phase II results were higher because according to RAC 1) technology used in the late 50's at SRS did not measure organic I-131 and thus underestimated the dose by about 5 times, and 2) Phase II results estimated that about 3/4 of the I-131 entering the sample line stuck to the sides of the line and was not monitored which means that actual releases were potentially about 4 times larger than measured by SRS. Note: We (Carlton) have disputed this big difference. The Phase II and Phase III I-131 totals differ considerably and ATL gives no reason for this difference.

The source terms from the various facilities were grouped by ATL using the locations shown in Figure 1. This was done to simplify the dose estimates and is appropriate. Over the 


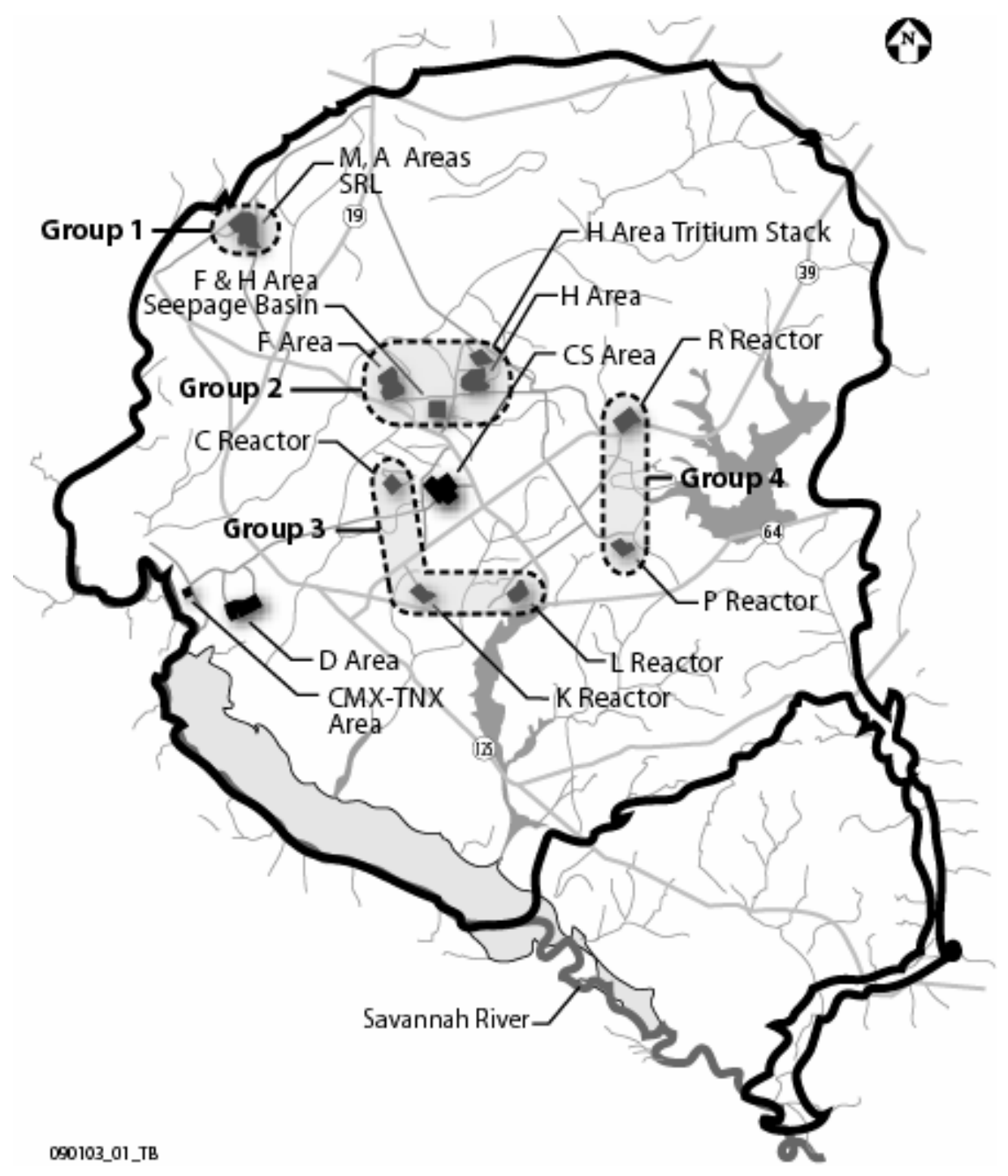

Figure 1 Virtual Source Locations used by ATL

years, dose estimates performed by Savannah River National Laboratory (SRNL) dose modelers for the annual environmental report have grouped by release locations as well.

\subsubsection{Scenario Selection}

ATL chose seven hypothetical exposure scenarios to estimate dose. These are represented in Figure 2 (figure taken from ATL report) and are listed below.

- Rural Family One

- Rural Family Two

- Urban/Suburban Family

- Migrant Worker Family
- Delivery Person Family

- Outdoors Person Family

- Near River Family 


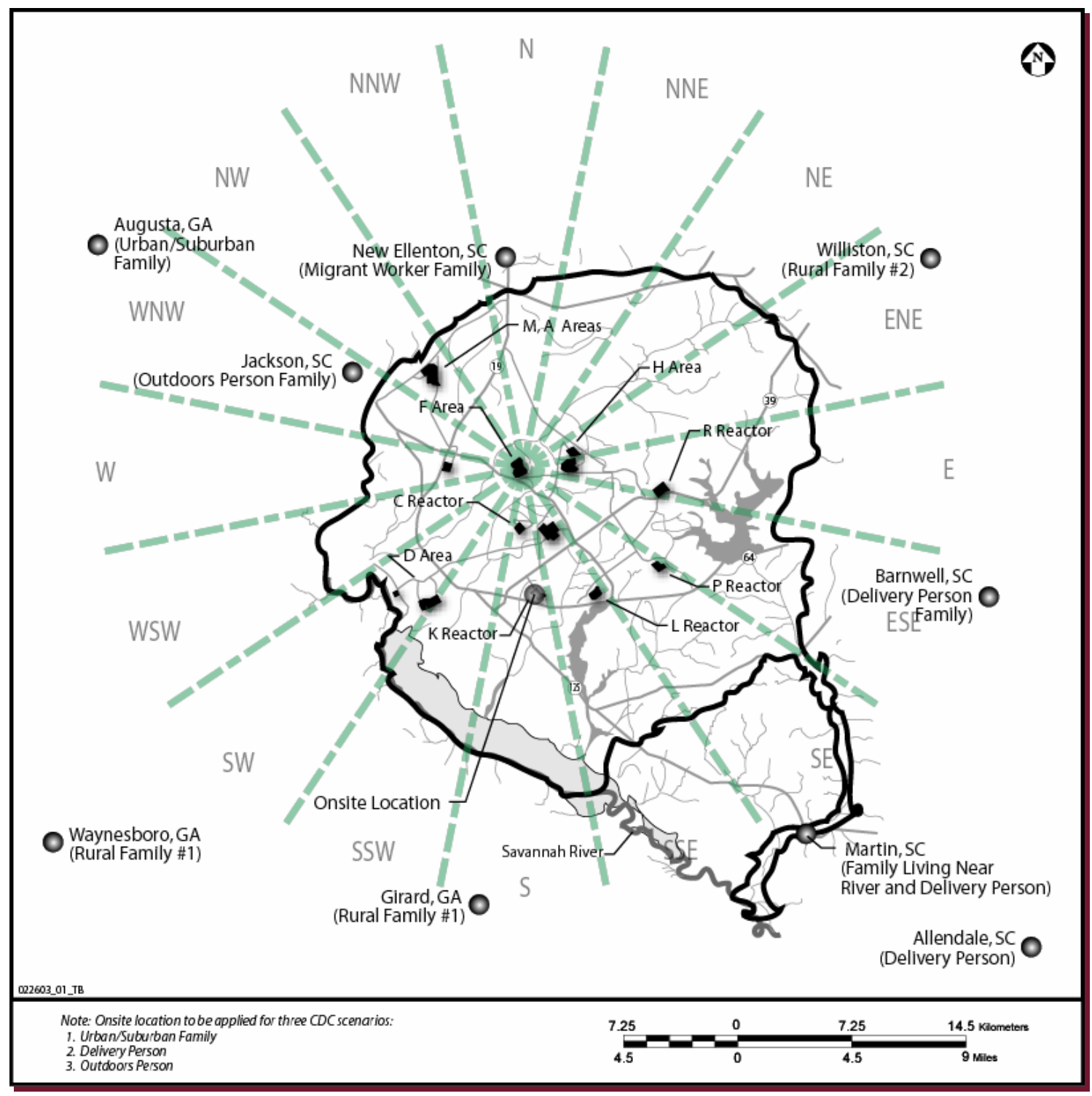

Figure 2 Scenarios Locations

These seven exposure scenarios and twelve exposure locations were used to model dose. Each hypothetical family includes a male and female (over age 18 in 1954) and a male child born in 1955 and another born in 1964. ATL states that these scenarios were meant to represent hypothetical families engaged in activities that were typical for the area.

Figure 3 shows the wind rose for $\mathrm{H}$ Area meteorological tower (Weber 2002). While winds at SRS do not predominately follow any particular sector, sectors where winds blow toward the NE have the highest frequencies (note in Figure 3 the wind frequencies are represent as blowing FROM the particular sector). ATL does include one scenario (Rural Family 2) in this region however they were a considerable distance from the boundary $(\sim 8 \mathrm{~km})$. Since ATL was striving to provide dose estimates for real families, they seemed to have selected 
areas with greater population rather than true rural areas. Selecting locations closer to the site boundary would have provided higher doses (about 50\% higher), but this dose would still be low in relation to dose from background sources.

The exposure scenario that ultimately results in the highest atmospheric dose is the outdoors person and it is discussed in detail here.

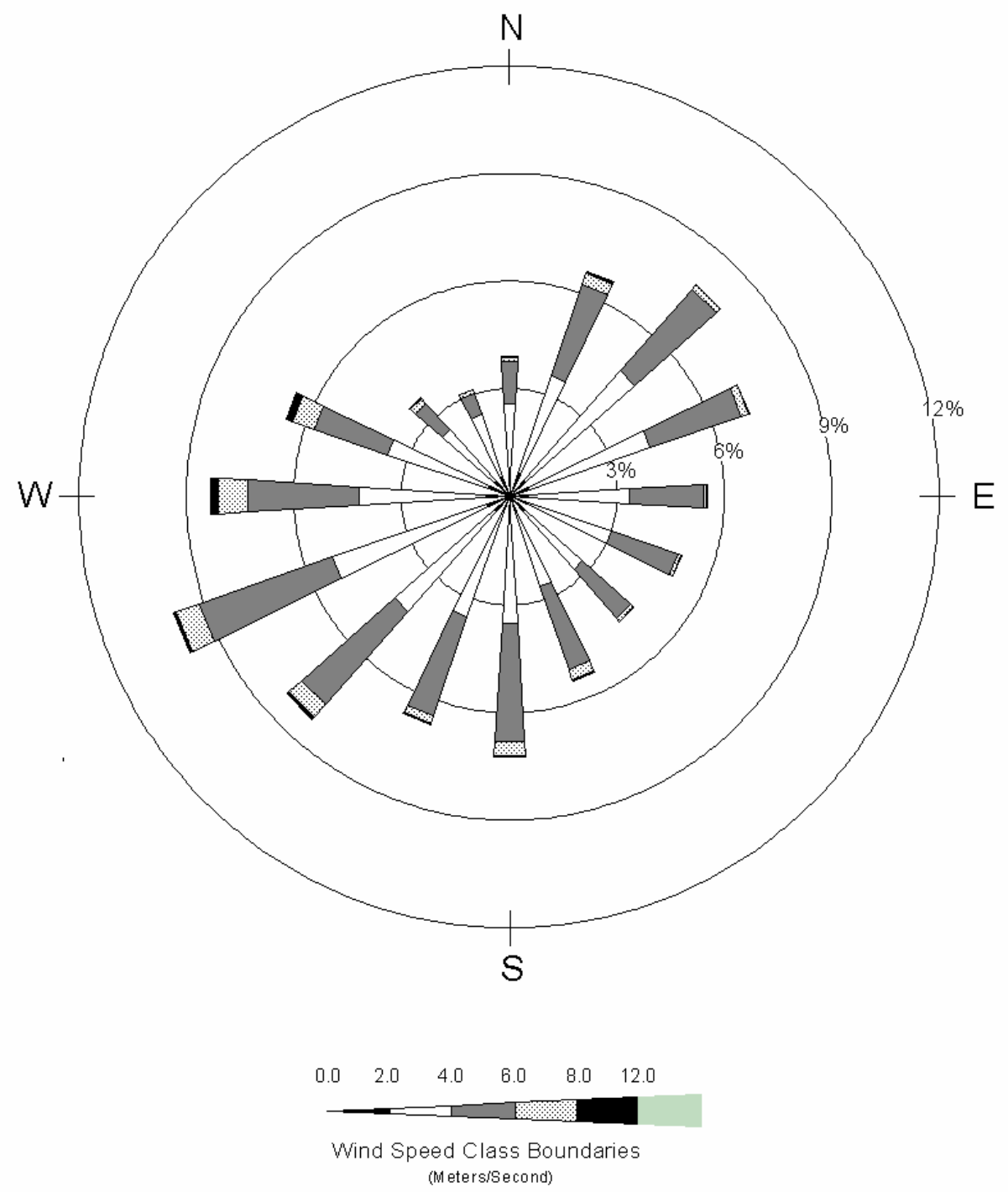

Note: the wind rose plot shown above depicts joint occurrence frequencies for wind direction sector (from which the wind blows) by wind speed category

Figure 3 Wind rose for $H$ Area 1997-2001 (Weber 2002) 


\subsubsection{Outdoors Person Family}

The outdoors person family lived in Jackson, SC where the family attended church and the children went to school. Much of the food eaten was grown in Jackson and the father worked and hunted at SRS. The location near K Reactor was assumed to be the work location and the hunting exposure location. The family swam and spent time boating along the Savannah River and ate fish that were caught in the Savannah River. The father also boated on the Savannah River while working.

Atmospheric dose pathways included for this scenario are shown in Table 2 along with dose pathways included in MAXDOSE-SR (Simpkins 1999) which is used for routine release dose modeling at SRS. Poultry and egg consumption pathways are not currently included in SRS dose estimates because chickens are typically housed in covered shelters and eat commercial feed (Hamby 1991). For the time period of interest for the dose reconstruction, it is feasible that 'backyard' chickens and eggs could have been more prominent and thus their inclusion is acceptable. Other pathways used by ATL but not by SRS include Inadvertent Soil Consumption and Inhalation of Resuspended Soil. These pathways are not expected to contribute much to the total dose and their inclusion is acceptable.

Table 2 Atmospheric Exposure Pathways included in Dose Reconstruction

\begin{tabular}{|l|c|c|}
\hline Exposure Pathway & ATL Dose Model & SRS Dose Model \\
\hline Plume Immersion & $\mathrm{x}$ & $\mathrm{x}$ \\
\hline Ground Shine & $\mathrm{x}$ & $\mathrm{x}$ \\
\hline Leafy Vegetable Consumption & $\mathrm{x}$ & $\mathrm{x}$ \\
\hline Root Vegetable Consumption & $\mathrm{x}$ & $\mathrm{x}^{\mathrm{a}}$ \\
\hline Fruit Consumption & $\mathrm{x}$ & $\mathrm{x}^{\mathrm{a}}$ \\
\hline Grain Consumption & $\mathrm{x}$ & $\mathrm{x}$ \\
\hline Beef Consumption & $\mathrm{x}$ & $\mathrm{x}$ \\
\hline Poultry Consumption & $\mathrm{x}$ & $\mathrm{x}$ \\
\hline Milk Consumption & $\mathrm{x}$ & \\
\hline Egg Consumption & $\mathrm{x}$ & $\mathrm{x}$ \\
\hline Inadvertent Soil Consumption & $\mathrm{x}$ & \\
\hline Inhalation & $\mathrm{x}$ & $\mathrm{X}$ \\
\hline Inhalation of Resuspended Soil & & \\
\hline
\end{tabular}

${ }^{\mathrm{a}}$ Within MAXDOSE-SR the Vegetable pathway includes all noted. 


\subsubsection{Dose Comparison for 'Child born in 1955 Outdoors Person' Scenario}

The highest dose for any receptor or scenario was for a child born in 1955 which resulted in a dose of 830 mrem from atmospheric pathways over the 39 year period. For an adult using maximum parameters over the same time period the dose was estimated by Carlton (1998) to be 77 mrem. Atmospheric pathway dose estimated by ATL for the adult male was 250 mrem. This dose estimated by Carlton is not expected to entirely agree with the ATL dose since the scenarios and release locations were different. Use of different source terms and age-specific dose factors will contribute significantly.

For routine dose modeling at SRS, doses are estimated for a hypothetical adult at 875 locations along the site boundary using MAXDOSE-SR (Simpkins 1999). Based on release location, these dose estimates are placed into 16 sectors and the highest dose is selected for each sector. Finally, the highest of the 16 sectors is reported as the dose to the maximally exposed individual (MEI). Exposure parameters are chosen to maximize dose and if average parameters are used the same highest sector method is used. Doses estimated for the Annual Environmental Reports and the Radiological Assessment Program are calculated for the MEI using parameters that would maximize dose. These estimates are for a hypothetical person which in high likelihood does not exist at that location.

Since H-3, Ar-41 and I-131 are considered the largest contributors to dose, these are compared in Table 3 as taken from the ATL report and from Carlton (1998). This comparison was performed for the adult male since this serves as a better comparison of actual doses. Notice that considering only these three radionuclides the ATL doses account for $97 \%$ of the dose reported above, but for Carlton only $61 \%$ of the dose is accounted for. Other radionuclides that have a significant impact according to Carlton are Strontium, Ru106 and Plutonium.

Table 3 Comparison of RAP Report Dose versus Phase III Dose

\begin{tabular}{|l|r|r|r|}
\hline & $\begin{array}{r}\text { Carlton } \\
\text { (mrem) }\end{array}$ & $\begin{array}{l}\text { ATL } \\
\text { (mrem) }\end{array}$ & \% diff \\
\hline H-3 & 18 & 23 & $22 \%$ \\
\hline Ar-41 & 7.8 & 30.6 & $75 \%$ \\
\hline I-131 & 21 & 190 & $89 \%$ \\
\hline Total & 46.8 & 243.6 & $81 \%$ \\
\hline
\end{tabular}

The differences in the I-131 doses are the greatest and I-131 is the largest dose contributor reported by both Carlton and ATL. For this reason I-131 atmospheric dose estimates performed by ATL and Carlton (1998) are further compared. Carlton (1998) does not provide a pathway-specific breakdown, so current SRS models were used to estimate these doses. Also, for consistency in comparing the models, the same source term that ATL used was input. Using SRS dose models for a single release from the center of the site, the 
Outdoors Person was assumed to be located in the NW Sector. Using a combination of MAXDOSE-SR (Simpkins 1999) and MAXINE (Simpkins 2002) doses were estimated for each pathway using the Jackson location and the ATL source term of 4.91E+04 Ci and these results are shown in Table 4. The largest difference is seen in the beef pathway with differences being nearly a factor of 40 . Looking at the last two columns, which show the percent of total dose, there is a difference in which pathway is the main contributor for ATL and SRS. These differences can be explained by the different parameter selections used by ATL versus SRS dose modeling each of which are discussed in detail in the following paragraphs.

Table 4 Pathway-Specific Dose Comparison for I-131

\begin{tabular}{|c|c|r|r|r|r|}
\hline $\begin{array}{c}\text { Exposure } \\
\text { Pathway }\end{array}$ & $\begin{array}{c}\text { ATL } \\
(\mathrm{mrem})\end{array}$ & $\begin{array}{c}\text { SRS } \\
(\mathrm{mrem})\end{array}$ & ATL/SRS & \multicolumn{1}{c|}{$\begin{array}{c}\text { A total } \\
\text { ATL }\end{array}$} & $\begin{array}{c}\text { \% total } \\
\text { SRS }\end{array}$ \\
\hline Vegetable Ingestion & 7 & 82 & 0.09 & $4 \%$ & $72 \%$ \\
\hline Beef Ingestion & 152 & 3.9 & 39.4 & $80 \%$ & $3 \%$ \\
\hline Milk Ingestion & 23 & 23.5 & 0.99 & $12 \%$ & $21 \%$ \\
\hline Inhalation & 6 & 2.8 & 2.25 & $3 \%$ & $2 \%$ \\
\hline Plume Shine & 0.04 & 0 & & $0 \%$ & $0 \%$ \\
\hline Ground Shine & 1 & 2.4 & 0.46 & $1 \%$ & $2 \%$ \\
\hline Total & 190 & 115 & 1.66 & & \\
\hline
\end{tabular}

Agreement is good between ATL and SRS for the inhalation pathway. Parameters that primarily affect this pathway are air concentration, breathing rate, and exposure time. Adult male breathing rates used by SRS and ATL are $8,000 \mathrm{~m}^{3} / \mathrm{yr}$ and $5548 \mathrm{~m}^{3} / \mathrm{yr}$, respectively. For the ATL estimates, the adult was assumed to work near K Area $2000 \mathrm{hrs} / \mathrm{yr}$ and thus the breathing was split accordingly. The principal difference equates to the fact that the person is assume to breathe air onsite while working $2000 \mathrm{hrs} / \mathrm{yr}$. Atmospheric dispersion air concentration predictions would yield higher concentration at this location since it is closer. This likely explains the inhalation dose predicted by ATL being higher than those predicted by SRS.

The difference in pathway dominance as shown in the last two columns is due to different parameter selections. ATL claims to have used a hierarchical method of assigning parameter values as stated in Chapter 4, page 4-19, but this does not seem to be the case. The method stated is to 1) use SRS specific values, 2) generic data from other sources (IAEA handbook(IAEA 1994)) and 3) as a last resort used GENII defaults. An extensive Land and Water Use Study was done in 1991 by Hamby (1991) which contains site-specific data for a variety of parameters used in dose modeling. ATL does refer to this document in most cases, but not as often as warranted. Another publication that is relevant, yet not cited by ATL is Simpkins and Hamby (2003) which looked at uncertainty in usage parameters during the 1950's at SRS. This study should be considered highly relevant to the dose reconstruction considering the time period of interest and the fact that it was published in a refereed Health Physics Journal. 
To further address the differences in Table 4, a comparison of usage parameters currently used by SRS and those used by ATL for the dose reconstruction for the adult male is shown in Table 5. Notice the discrepancy in ratios for beef versus the vegetable and milk consumption. In particular, the beef ingestion value used by ATL is higher by about a factor of two. Further investigation yielded errors in assignment of this variable.

Table 5 Usage Value Comparison

\begin{tabular}{|l|r|r|r|}
\hline & ATL & $\begin{array}{l}\text { SRS } \\
\text { Average }\end{array}$ & $\begin{array}{l}\text { ratio } \\
\text { ATL/SRS }\end{array}$ \\
\hline $\begin{array}{l}\text { Vegetable ingestion } \\
(\mathrm{kg} / \mathrm{yr})\end{array}$ & 71.3 & 163 & 0.4 \\
\hline Beef ingestion $(\mathrm{kg} / \mathrm{yr})$ & 78.1 & 43 & 1.8 \\
\hline Milk ingestion $(\mathrm{kg} / \mathrm{yr})$ & 73.7 & 120 & 0.6 \\
\hline
\end{tabular}

Instead of using site-specific data, ATL chose to use the EPA's Exposure Factors Handbook (U.S. EPA 1997). While this data has a high degree of research backing it up, their application of the meat data was incorrect. ATL included summation of meat 'mixtures' which includes only $22 \%$ beef and pork with the rest being vegetables and grains. For instance, for the infant the following meat types were summed by ATL: beef $(9 \mathrm{~g} / \mathrm{d})$, Pork (4 g/d) Lamb, Veal, Game (3 g/d) Processed meats (2 g/d) and Meat Mixtures (51 g/d) which resulted in $69 \mathrm{~g} / \mathrm{d} * 365 \mathrm{~d} / \mathrm{yr}=25 \mathrm{~kg} / \mathrm{yr}$. However, the meat mixture should have been reduced by a factor of 0.22 to $11 \mathrm{~g} / \mathrm{d}$ which would result in a total of $29 \mathrm{~g} / \mathrm{d} * 365 \mathrm{~d} / \mathrm{yr}=11$ $\mathrm{kg} / \mathrm{yr}$. This would reduce the dose to the infant from consumption of beef by more than a factor of two. All other receptors and locations should be corrected as well.

The significance of this pathway is further increased by the fact that $75 \%$ of the beef consumption is assumed to be venison from deer taken on the Site. This assumption is extremely conservative especially since it is considered over the entire 39-yr period. The reference ATL cites (Lockridge 2002) is an unpublished working group study. The fact that is in unpublished gives little credibility to the work. Controlled hunts at SRS did not begin until 1965 and weapons such as guns and cross bows have always been prohibited onsite. This assumption of a high percentage of beef consumption coming from onsite is further discredited for the entire family because of the quantity of meat that would be necessary to feed the family. Table 6 shows the maximum edible weight taken offsite by a hunter for the period of 1993-2004. ATL claims that a family of four (includes infant and child) would eat about $200 \mathrm{~kg}$ of beef a year of which $75 \%$ ( $150 \mathrm{~kg}$ ) were obtained onsite. Since the table below reports the maximum amounts it is not feasible to assume you could feed a family of four when you are analyzing doses for a reasonable, average scenario. A more reasonable assumption would be that beginning in 1965 (when the controlled hunts began) some small portion of the diet includes venison from onsite.

As to why the vegetable and milk usage values differ so much, the answer is not quite as apparent, but is likely what types of milk products and vegetable products were used by SRS and ATL. 
Site-specific agricultural parameters were not used and transfer factors differ which further contributes to the difference in which pathways dominate. Transfer factors refer to the ratio of concentrations of a radionuclide in two compartments under equilibrium conditions. Transfer factors used for I-131 are shown in Table 7 for each pathway. ATL used GENII defaults for transfer factors which were higher than those routinely used at SRS. The primary source for SRS transfer factors is U.S. Nuclear Regulatory Guide 1.109 (U.S. NRC 1977) and GENII uses a wide variety of references for transfer factors. For the beef pathway for iodine, ATL used the GENII default which comes from IAEA (1994). Both the current SRS value and the ATL value come from credible sources, so neither is considered to be superior to the other.

\section{Table 6 Maximum Edible Weight from Onsite Deer Hunts}

\begin{tabular}{|r|r|}
\hline & \multicolumn{1}{|l|}{$\begin{array}{l}\text { Edible } \\
\text { Weight } \\
(\mathrm{kg})\end{array}$} \\
\hline 1993 & 171 \\
\hline 1994 & 260 \\
\hline 1995 & 74 \\
\hline 1996 & 117 \\
\hline 1997 & 171 \\
\hline 1998 & 115 \\
\hline 1999 & 127 \\
\hline 2000 & 43 \\
\hline 2001 & 293 \\
\hline 2002 & 65 \\
\hline 2003 & 57 \\
\hline 2004 & 116 \\
\hline Average & 134 \\
\hline
\end{tabular}

Table 7 I-131 Transfer Factors Used by ATL and SRS

\begin{tabular}{|l|c|c|c|}
\hline & ATL & SRS & $\begin{array}{c}\text { Ratio } \\
\text { ATL/SRS }\end{array}$ \\
\hline Vegetable (unitless) & $2.0 \mathrm{E}-02$ & $2.0 \mathrm{E}-02$ & 1 \\
\hline Meat (d/kg) & $4.0 \mathrm{E}-02$ & $2.9 \mathrm{E}-03$ & 13.8 \\
\hline Milk (d/L) & $1.0 \mathrm{E}-02$ & $6.0 \mathrm{E}-03$ & 1.7 \\
\hline
\end{tabular}

Another reason for the differences in pathway contributions is that the agricultural productivities used by SRS and those used by ATL differ considerably. Agricultural productivity refers to the amount of a commodity produced per unit area. ATL productivity parameters versus SRS values are reported in Table 8. Productivity is inversely proportional 
to concentration in vegetation via the contamination on plant surface pathway, therefore lower productivities produce higher doses. This further explains the disparity in Table 4.

Table 8 Productivities used by ATL and SRS

\begin{tabular}{|l|c|c|c|}
\hline & SRS & GENII & $\begin{array}{c}\text { Ratio } \\
\text { GENII/SRS }\end{array}$ \\
\hline $\begin{array}{l}\text { Vegetabl } \\
\text { e }\end{array}$ & 0.7 & 0.7 & 1.0 \\
\hline Meat & 1.8 & $1.8 / 0.7$ & $1 / 2.6$ \\
\hline Milk & 1.8 & $1.8 / 0.7$ & $1 / 2.6$ \\
\hline \multicolumn{4}{|c}{ * Forage/Grain productivities }
\end{tabular}

In summary, the ATL and SRS have estimated different atmospheric doses over the same time period of interest primarily because of different input parameters used within the models. If SRS models are adjusted to assume use of all the parameters that ATL used the doses agree quite well (within a factor of 2). This shows that the principal methods used by the two models are in agreement with likely inherent differences being in the air concentrations being modeled by four release locations rather than the one at the center of site that is currently used at SRS.

\subsection{Liquid Release Pathway}

ATL estimated doses from aqueous releases for 21 radionuclides including the following pathways: fish ingestion, incidental ingestion of water while swimming, swimming, boating, and shoreline exposure. The primary contributors to dose were Cs-137, Sr-90, and P-32 and these radionuclides will be discussed in detail.

\subsubsection{Source Term}

Liquid source term documentation in the dose reconstruction report is lacking. Source terms are listed with no references and differences are not discussed. Tables are not clearly labeled, so it is difficult to tell exactly what values were used for the dose reconstruction, but Table 9 shows the source term values that were assumed to be used based on unclear data. The differences for each radionuclide are discussed as data permits.

Table 9 Liquid Release Source Terms

\begin{tabular}{|c|c|c|c|c|c|}
\hline & & & & $\%$ diff & $\%$ diff \\
\hline Rad & $\begin{array}{c}\text { SRS } \\
\text { AER } \\
(\mathrm{Ci})\end{array}$ & $\begin{array}{c}\text { Phase II } \\
\text { Total } \\
\text { (Ci) }\end{array}$ & $\begin{array}{c}\text { Phase III } \\
\text { Total } \\
\text { (Ci) }\end{array}$ & (P3-SRS)/P3 & (P3-P2)/P3 \\
\hline P-32 & 36 & 196 & 129 & $72 \%$ & $-52 \%$ \\
\hline Sr-90 & $110 / 150^{*}$ & 100 & 460 & $-65 \%$ & $78 \%$ \\
\hline Cs-137 & 210 & 250 & 257 & $18 \%$ & $3 \%$ \\
\hline
\end{tabular}


Source terms from Phase II were adjusted by correction factors to account for differences between measured and modeled results. Application of these adjustment factors were applied on a yearly basis which would perhaps explain the large differences between the Phase II and Phase III source terms. For strontium-90, the documentation states that the unidentified beta-gamma releases in the amount of $218.8 \mathrm{Ci}$ were added 'before multiplication by the adjustment factor for strontium-90'. These source terms were used for the dose estimates for the receptor along the Savannah River, but measured data was used for the Lower Three Runs receptor.

\subsubsection{Scenario Selection}

Of the seven scenarios (discussed in section 0) only 3 included exposure to SRS releases via surface water: delivery person family, outdoors person family and near river family. Exposure locations varied for the scenarios as shown in Table 10. The Savannah River downstream exposure location included radionuclides discharged into the river via the Savannah River Swamp and the Lower Three Runs Creek. The Outdoors Person Family Adult Male was assumed to spend additional hours on the shoreline as part of work. Incidental ingestion during swimming is also considered.

Inclusion of the ingestion of fish from the Lower Three Runs for the delivery person family is very conservative. While these trespassing activities may have occurred, the likelihood of them occurring yearly for the entire 39 year period is unrealistic. Furthermore to assume half of the yearly intake of fish is from this region adds further conservatism.

Table 10. Exposure Locations for Surface Water Releases by Scenario

\begin{tabular}{|l|l|c|c|}
\hline Scenario & Exposure Pathway & $\begin{array}{l}\text { Savannah River } \\
\text { Downstream }\end{array}$ & Lower Three Runs \\
\hline $\begin{array}{l}\text { Delivery Person } \\
\text { Family }\end{array}$ & $\begin{array}{l}\text { Fishing,swimming,shoreline } \\
\text { Fishing,shoreline,boating }\end{array}$ & $\mathrm{X}$ & $\mathrm{X}$ \\
\hline $\begin{array}{l}\text { Outdoors Person } \\
\text { Family }\end{array}$ & $\begin{array}{l}\text { Fishing,shoreline,boating } \\
\text { Swimming }\end{array}$ & $\mathrm{X}$ & \\
\hline Near River Family & $\begin{array}{l}\text { Fishing,boating,swimming } \\
\text { and shoreline }\end{array}$ & $\mathrm{X}$ & \\
\hline
\end{tabular}

The outdoors person family is assumed to swim elsewhere

Ingestion of contaminated drinking water and irrigation of crops with contaminated water was not considered during the dose reconstruction. Currently at SRS these pathways are considered in the Annual Environmental Reports. However there are no water distribution plants near the perimeter of the site so the likelihood of the ingestion pathway is small. The significance of the irrigation pathway is minimal when compared to the fish ingestion dose, so total dose is not expected to change by including this pathway. 


\subsubsection{Dose Comparison with 'Delivery Person Adult'}

The scenario that produces the largest aqueous dose is the Delivery Person Family with an estimated dose of 570 mrem for the adult male. Referring to Carlton (1998) the MEI dose over the same period from liquid releases was 140 mrem. This comparison is further broken down by principal radionuclides (according to ATL) and this comparison is shown in Table 11. Carlton uses maximum exposure values whereas ATL used average values, so the disparity is even greater than expected.

Table 11 Liquid Dose Comparison by Radionuclide for Delivery Person Adult

\begin{tabular}{|l|r|r|c|}
\hline & $\begin{array}{c}\text { Carlton } \\
\text { (mrem) }\end{array}$ & $\begin{array}{l}\text { ATL } \\
\text { (mrem) }\end{array}$ & $\begin{array}{c}\% \\
\text { difference }\end{array}$ \\
\hline Cs-137 & 61 & 470 & $87 \%$ \\
\hline P-32 & 46 & 27 & $-73 \%$ \\
\hline Sr-90 & 3 & 59 & $96 \%$ \\
\hline
\end{tabular}

Looking at Table 11, the most significant difference is seen in the Cs-137 dose so this difference is investigated further. For Cs-137, ingestion of fish is the dominant pathway. ATL assumed the ingestion of fish occurred in equal portions (4.95 kg each) from the Savannah River and Lower Three Runs Creek. In Carlton (1998) fish was consumed at a rate of $19 \mathrm{~kg} / \mathrm{yr}$ from the Savannah River. Since Carlton assumes a fish ingestion rate more than double of that that ATL used, this makes the disparity in dose even greater than expected.

For the Savannah River fish estimates, water concentration was estimated using GENII and then a bioaccumulation factor was applied to estimate the concentration in fish and ultimately dose. For Lower Three Runs, actual water concentrations from SRS Annual Environmental Reports were used which results in much higher water concentrations and hence dose. For both the Savannah River Fish estimates and the Lower Three Runs fish estimates, a bioaccumulation factor of $4700 \mathrm{~L} / \mathrm{kg}$ was used for Cesium. SRS currently uses a value of $3000 \mathrm{~L} / \mathrm{kg}$ (Jannik 2003) for their bioaccumulation factor. The value used by ATL does not follow the logic they stated for assignment of this variable and should be technically justified or modified. This difference coupled with the use of actual water concentration in Lower Three Runs accounts for a majority of the differences. ATL makes no mention of Par Pond's effect on concentrations in Lower Three Runs. A better comparison would be between SRS doses and the Near River Family adult since both of these receptors assume all fish ingested are from the Savannah River.

\subsubsection{Dose Comparison with 'Near River Adult'}

The Near River Adult is assumed to consume fish from the Savannah River at a rate of 9.9 $\mathrm{kg} /$ year which would be a more realistic scenario and a better comparison with existing SRS data. The Near River Adult doses are compared with Carlton (1998) as shown in Table 12 . These doses show much better agreement. The difference in the Sr-90 results from different bioaccumulation factors being used. SRS uses the U.S. NRC Value of $30 \mathrm{~L} / \mathrm{kg}$ and ATL 
used a value of $450 \mathrm{~L} / \mathrm{kg}$. The ATL value appears to have been assigned in error. Statements are made about calculating the geometric mean of several values, but the results do not support their statements. The SRS value is much closer to the IAEA (1994) value of $60 \mathrm{~L} / \mathrm{kg}$.

Table 12 Liquid Dose Comparison by Radionuclide for Near River Adult

\begin{tabular}{|l|r|r|r|}
\hline & $\begin{array}{l}\text { Carlton } \\
\text { (mrem) }\end{array}$ & $\begin{array}{l}\text { ATL } \\
\text { (mrem) }\end{array}$ & $\begin{array}{l}\text { \% } \\
\text { difference }\end{array}$ \\
\hline Cs-137 & 61 & 62 & $2 \%$ \\
\hline P-32 & 46 & 53 & $13 \%$ \\
\hline Sr-90 & 3 & 13 & $81 \%$ \\
\hline
\end{tabular}

\section{CONCLUSIONS}

Dose reconstruction efforts directed by CDC have been reviewed in detail. Inconsistencies with current SRS methods and errors have been noted. ATL's scenarios involving workers taking home large amounts of venison for their families' consumption and the trespasser/poacher along the Lower Three Runs Creek Fishing are unrealistic and thus result in higher doses than previously predicted by SRS. Other contributing factors to dose differences include ATL's lack of using site-specific parameters and incorrect interpretation of EPA's exposure factors. Even with ATL using these conservative scenarios, the doses, as they point out, are minimal when compared to the background that would be received over the same time period.

4. 


\section{REFERENCES}

Carlton, W.H. Assessment of Radionuclides in the Savannah River Site Environment Summary. Westinghouse Savannah River Company Report: WSRC-TR-98-00162, Aiken, SC, 1998.

Hamby, D.M. Land and Water-Use Characteristics in the Vicinity of the Savannah River Site. Westinghouse Savannah River Company Report: WSRC-RP-91-17, Aiken, SC, March 1991b.

IAEA: Handbook of Parameter Values for the Prediction of Radionuclide Transfer in Temperate Environments. International Atomic Energy Agency Technical Report Series No. 364, Vienna, Austria, 1994.

Jannik, G.T. Cesium-137 Bioconcentration Factor for Freshwater Fish in the SRS Environment. Westinghouse Inter-Office Memorandum: SRT-EST-2003-00134, Aiken, SC 2003.

Napier, B. A., R. A. Peloquin, D. L. Strenge, and J. V. Ramsdell. GENII - The Hanford Environmental Radiation Dosimetry Software System. PNL-6584, Vols. 1-3. Pacific Northwest Laboratory, Richland, Washington 1988.

Simpkins, A.A. MAXDOSE-SR: A Routine Release Atmospheric Dose Model Used at SRS. Westinghouse Savannah River Company Report: WSRC-TR-99-00281, Aiken, SC, 1999a.

Simpkins, A.A. Software Quality Assurance Plan for Environmental Dosimetry. Westinghouse Savannah River Company Report: WSRC-RP-94-1159, Aiken, SC, 1999.

Simpkins, A.A. and D.M. Hamby, Uncertainty in Transport Factors used to Calculated Historical Dose from I-131 Releases at the Savannah River Site. Health Physics Journal: 85(2), 2003.

Till, J.E., et al. Savannah River Site Environmental Dose Reconstruction Project, Phase II : Source Term Calculations and Ingestion Pathway Data Retrieval, Evaluation of Materials Released from the Savannah River Site. RAC Report No. 1-CDC-SRS1999-Final. Risk Assessment Corporation (RAC). Available from URL: http://www.cdc.gov/nceh/radiation/savannah/ April 30, 2001.

U.S. Environmental Protection Agency, Exposure Factors Handbook Volume II: Food Ingestion Factors. EPA/600/P-95/0002Fb, Washington, DC, 1997. 
U.S. Nuclear Regulatory Commission, Calculation of Annual Dose to Man from Routine Releases of Reactor Effluents for the Purpose of Evaluating Compliance with 10CFR50 Appendix I. Regulatory Guide 1.109, Rev 1, Washington, DC, October 1977.

Weber, A.H. Summary of Data and Steps for Processing the SRS 1997-2001 Meteorological Database(U). Westinghouse Savannah River Company Report: WSRC-TR-200200445, Aiken, SC 2002. 


\section{Appendix A. Technical Comments}




\section{Appendix A. Technical Comments}

\section{General Comments}

1. Reference form varies by chapter. Some use numerical reference while others use author-date format. Author-date format is preferred in most peer-reviewed publications and hence should be used here.

2. There is not sufficient data description to reproduce any calculations. At least a sample input file containing ALL data should be shown to allow for verification of inputs.

3. The document is not written for the general public. Too much detail on models is supplied in some chapters (i.e. Chapter 8).

4. There does not appear to be organization between chapters. Some information is reproduced in chapters almost verbatim rather than referring to previous chapters.

5. The uncertainty analysis performed was technically flawed and is of questionable value. Many parameters which should have been considered uncertain were not. Also the number of realizations was far too low (40) for the results to be of any value.

\section{Specific Comments}

The following list contains specific technical comments which refer to specific locations within the report as noted. First the page number is listed and then the line number if available.

1. Vii, urban/suburban family, It is sufficient to say downtown Augusta (for example, Broad and Greene do not intersect).

2. xi, Figures 3-7 are illegible

3. 1-6, Three step process. ATL claims to have used this three step process for the assignment of variables, but this does not occur in many instances. See later comments.

4. 3-7, Table 3 and line 9 of page 3-8. These two are not in agreement. Was the family assumed to swim and have shoreline exposure at Lower Three Runs?

5. 3-22, lines 5-10, Citations of unpublished studies from several years ago is unacceptable. Only published data should be used for this effort.

6. 4-3, line 23, These reports should be referred to as 'Federal Guidance Reports 11,12 and 13 ' and should include references for each of these. 
7. 4-12, lines 18-19, The receptor behavior is highly uncertain and should be considered in any uncertainty assessments that are done. The logic not to include them as uncertain because they are hypothetical scenarios is completely flawed. Virtually all computer modeling of dose is for hypothetical individuals.

8. 4-12, line 27, The statement that SRS-specific data 'frequently were not available' is untrue. SRS dose models use site-specific parameters a majority of the time and these instances are well documented (Hamby 1991).

9. 4-14, line 28, A sentence should be added stating how the age-specific dose conversion factors were applied - within the GENII run or as part of the postprocessors.

10. 5-3, line 17, If the screening values represent $\%$ of total dose, so state. It is currently unclear as to what the screening value refers to.

11. 5-8, line 26, The actual location of each of the four release points should be listed in site coordinates or by a site landmark, i.e. canyon stack.

12. 6-1, line 12, The release height is not an 'atmospheric process'. Perhaps change to atmospheric inputs.

13. 6-5, line 18, State which 4 data sets were used by time period. Also state which meteorological data tower they were taken from onsite.

14. 6-7, line 8, Show release coordinates in this Table also.

15. 7-5, step L-5. How was this accomplished? Provide more details.

16. 7-27, section 7.4.3. State how data for other radionuclides was obtained. Very few were listed in the annual environmental reports in the early years.

17. 8-7, line 12, State references for all values in Table.

18. 8-8, Both Tables, Provide references for all values.

19. 8-11, Tables, Provide references for all values.

20. 8-11, line 13, For all units in the table the numerator should be 'd' and not 'kg'.

21. 8-13, line 20, Neither poultry nor egg animal feed values are listed in Hamby 1991 as stated. These pathways are discounted within Hamby 1991. List the correct reference.

22. 8-14, Both Tables need references.

23. 9-17, lines 9-14, State what data was taken from the exposure factors handbook. Was it data for ingestion of corn or for ingestion of total grains? 
24. 9-18, line 10-12, Three-quarters of the beef ingested by the outdoors person family to come from deer on SRS is unrealistic. Controlled hunts at SRS did not begin until 1965 and weapons such as guns and cross bows are prohibited for onsite employees. This assumption is further discredited for the entire family because of the quantity of meat that would be necessary to feed the family. See Section 2.1.3 for further discussion on problems with this scenario.

25. 9-19, Table 9-16, All values in this Table are wrong due to the incorrect summation of different food types contained within the Exposure Factors Handbook. ATL included summation of meat 'mixtures' which includes only $22 \%$ beef and pork with the rest being vegetables and grains. For instance, for the infant the following meat types were summed by ATL: beef (9 g/d), Pork (4 g/d) Lamb, Veal, Game (3 g/d) Processed meats (2 g/d) and Meat Mixtures (51 g/d) which resulted in $69 \mathrm{~g} / \mathrm{d} * 365$ $\mathrm{d} / \mathrm{yr}=25 \mathrm{~kg} / \mathrm{yr}$. However, the meat mixture should have been reduced by a factor of 0.22 to $11 \mathrm{~g} / \mathrm{d}$ which would result in a total of $29 \mathrm{~g} / \mathrm{d} * 365 \mathrm{~d} / \mathrm{yr}=11 \mathrm{~kg} / \mathrm{yr}$. This would reduce the dose to the infant from consumption of beef by more than a factor of two. All other receptors and locations should be corrected as well.

26. 10-7, line 9, Give reference for these values.

27. 12-6, Section 12.3.1 State that the determination of these variables will be discussed later.

28. 12-8, List reference for each distribution.

29. 12-9, Section 12.4.2. The first listed reason for excluding parameters from the uncertainty analysis is not valid. Many of the receptor parameters have a high degree of uncertainty.

30. 12-11, first paragraph, Source terms are highly uncertain and therefore should not be eliminated from the uncertainty analysis.

31. 12-17, Section 12.5, 40 realizations are not enough to perform an uncertainty analysis.

32. 12-18, Section 12.5.1, No basis is stated for assigning a lognormal distribution to the variables. Distributions should be assigned based on ranges of values and not universally assigned for all variables.

33. 12-27 last paragraph, This paragraph attempts to explain why differences exist between the median dose calculated used the uncertainty analysis and the point estimate dose, but fails to do so. Explain the difference.

34. 12-30, Section 12.6.2. Insert Table showing the correlation coefficients for all of the variables.

35. 13-1, line 27, Spell out 'iodine' rather than say 'I' 
36. 13-3, Table 13-2, The title of the Table appears to be incorrect since it includes the atmospheric component as discussed on Page 13-2 line 34. Remove 'from Fish Ingestions' from the title.

37. 13-4, First paragraph is a repeat of the previous paragraph so remove it.

38. 13-4, lines 18 and 19. Percentages would not be affected by doubling the dose so remove this statement and also from the next Table as well.

39. A- $1,1^{\text {st }}$ bullet, For short time periods the release rate would have units more likely to be $\mathrm{Ci} / \mathrm{s}$ or $\mathrm{Ci} / \mathrm{hr}$, but not $\mathrm{Ci} / \mathrm{yr}$.

40. A-3, Last paragraph, The meteorological data does not contain 'five year averages' but rather five years of meteorological data. Also, what is meant by a '20-yr average'?

41. A-4, Last line, State site coordinates for the virtual release locations.

42. A-9, Section A.2.2.1 Last line. Is it appropriate to assume equal weighting of the sources considering some facilities tend to release more than others?

43. A-12, Table A-5 through A-8, Isn't the second to last column really the weighted sum? If so, state.

44. D-6, $2^{\text {nd }}$ paragraph, If concentrations in deer are not above background level, this gives another reason for this pathway not to be included.

45. D-9, Dose and Risk Module Section, States 'almost all dose and risk factors'. If dose and risk factors were not taken from FGR 13, then they need to be listed and justification provided.

46. D-11, Figure D-2 is not relevant to this study since transport was considered over long distances and individual structures were not considered.

47. D-13, Release Height discussion. General statements about concentrations in relation to site boundary offer not input if distances are not included. The statement from Till and Meyer is not relevant to this study so remove.

48. D-14, Section D.2.1.6. Not relevant to dispersion over the distances considered here. Remove or so state.

49. D-14, Section D.2.1.7. Was Topography considered for the dose reconstruction? So state.

50. D-16, Section D.2.2.2. Compass direction should be listed in the order in which they appear. Correct to list as N, NNE, NE, ENE, E. 
51. D-16, Section D.2.2.2. Statement about 10-degree sectors is incorrect. SRS uses 22.5 degree sectors.

52. F-7, Strontium Water-to-Freshwater Fish. The rational for assignment of this variable is completely flawed. There is incorrect citing data from the reference as well as errors in the estimation of the means. This parameter needs to be reevaluated.

53. F-7, Cesium Water-to-Freshwater Fish. It is unclear how the variable assignment was made. Reference is made to geometric average which the results do not support. This parameter needs to be reevaluated. Also units on this parameter are incorrect. They should be $\mathrm{L} / \mathrm{kg}$.

54. T-139, table, this table refers to three children whereas, on page 3-9 line 33, it states each exposure scenario consists of 2 children. 
$\underline{\text { Technical Review Of SRS Dose Reconstruction Methods Used By CDC }}$

\section{DISTRIBUTION (13)}

R.A. Pedde, 730-1B

G.T. Wright, 773-A

M.A. Schmitz, 730-4B

P.M. Allen, 742-A

J.R. Yanek, 730-4B

H.J. Stafford, 730-4B

D. B. Moore-Shedrow, 773-A

K.W Crase, 730-4B

P. Fledderman, 735-B

J.B. Gladden, 773-42A

D. Gordon, 742-A

J. D. Heffner, 735-B

G.T. Jannik, 773-42A

P.L. Lee, 773-42A
A. A. Simpkins, 773-42A
A.L.Towns, 730-B
G.R. Whitney, 730-B
C.E. Radford, 730-B
ED Records(3), 773 - 42A 